\title{
THE EFFECT OF ONLINE ADVERTISING (ONLINE ADVERTISING) ON CONSUMER BUYING INTEREST IN BUYING APPLICATIONS ONLINE WITH CUSTOMER SATISFACTION AS INTERVENING VARIABLE \\ (Case Study on Students of the Faculty of Economics and Business, Malikussaleh University)
}

\author{
Asy'Ari Nisfullah $^{1}$, Armianto ${ }^{2}$, Nazaina $^{3}$ \\ Faculty of Economics and Business, Universitas Malikussaleh \\ E-mail: nazaina@unimal.ac.id
}

\begin{abstract}
The results of this study show. (1) It can be seen that the adjusted $R$ square value is 0.758 or $75.8 \%$. This shows that consumer satisfaction $(Y 1)$ and advertising $(X)$ can explain buying interest (Y2) by $75.8 \%$, the remaining $24.2 \%(100 \%-75.8 \%)$ is explained by other variables outside the research model. this. Such as service, price and buying interest. (2) The results of the t-test (partial) can be seen that the obtained tcount (7.413) > ttable (1.685), as well as the significance value of $0.00<0.05$, it can be concluded that the first hypothesis is accepted, meaning that the advertising variable $(X)$ has a positive and significant effect on consumer satisfaction (Y1). (3) The results of the t-test (partial) can be seen that the value of tcount (3.059) > ttable (1.685), and the significance value of $0.00<0.05$, it can be concluded that the second hypothesis is accepted, meaning that advertisement $(X)$ has a positive and significant effect on buying interest (Y2). (4) obtained tcount value of 7.413 With $=5 \%$, ttable $(5 \%$; nk $=38)$ obtained ttable value of 2.024 From the description it can be seen that tcount (7.413) > ttable (2.024), as well as the significance value of $0.00<0.05$ then it can be concluded that the first hypothesis is accepted, meaning that the advertising variable $(X)$ has a positive and significant effect on consumer satisfaction $(Z)$. obtained tcount value of 3,059 With $=5 \%$, ttable $(5 \%$; $n k=38)$ obtained ttable value of 2,024 From this description it can be seen that tcount $(3,059)>$ ttable $(2,024)$, and the significance value is $0,004<$ 0,05 then it can be concluded that the second hypothesis is accepted, meaning that advertising $(X)$ has a positive and significant effect on buying interest $(Y)$. obtained tcount value of 4.492 With = $5 \%$, ttable (5\%; $n k=38)$ obtained ttable value of 2.024 From the description it can be seen that tcount (4.492) > ttable (2.024), and the significance value is $0.00<00.05$, it can be concluded that the third hypothesis is accepted, meaning that consumer satisfaction (Z)positive and significant effecton buying interest $(Y)$. In the path analysis test it can be seen that the direct effect of advertising $(X)$ on buying interest $(Y)$ is greater than the indirect effect through advertising variable $(X)$, on buying interest $(Y)$ through consumer satisfaction $(Z)$. This means that consumer satisfaction advertising is an intervening variable on the relationship between the influence of advertising on buying interest.
\end{abstract}

\section{Keywords: advertising, consumer satisfaction, and buying interest}

\section{BACKGROUND}

Consumer behavior in deciding to buy a product is a special study for each company before releasing its products to the market. The development of the digital age is increasingly inevitable that every company must adjust its marketing strategy by including an online system to sell its products. Online shopping has become a habit for some people because of the convenience it provides, many people think that online shopping is a means to find the items they need. The research method used is to compare the results of research and journals that examine online shopping in Indonesia. Then reviewed and reviewed the existing theory of consumer behavior so that it can be concluded that the considerations of consumers shopping online at an online 
THE EFFECT OF ONLINE ADVERTISING (ONLINE ADVERTISING) ON CONSUMER BUYING INTEREST IN BUYING APPLICATIONS ONLINE WITH CUSTOMER SATISFACTION AS INTERVENING VARIABLE

(Case Study on Students of the Faculty of Economics and Business, Malikussaleh University)

Asy'Ari Nisfullah, Armianto, Nazaina

storeShopping decisions usually require considerations that really support and can benefit buyers such as location and price factors. Buyers tend to choose to shop at supermarkets that have strategic locations.

Schnaars (Harbani Pasolong, 2010: 221) states that: The creation of customer or community satisfaction can provide benefits, including: the relationship between customers and agencies becomes harmonious, provides a good basis for repeat buyers (use), creates customer loyalty and forms recommendations. word of mouth, all of which benefit the company. If it is reviewed further, the achievement of community satisfaction through service quality can be improved by several approaches.

Understanding buying interest according to Kotler and Keller (2011), "Purchase interest is a behavior that appears in response to objects that indicate a consumer's desire to make a purchase". Because every consumer has the right to comfort, security, correct and honest information and the right treatment or service for what is purchased, every company or producer is required to provide a form of prime service to its consumers. This fact can be seen, that there are several things that can increase consumer buying interest, namely the total customer value consisting of product value, service value, personal value, image value, and total customer cost consisting of monetary costs, time costs, costs energy, and thought costs.E-commerce product price comparison service provider, iPrice recently released the results of their study on consumer behavior when shopping online in Southeast Asia with a focus on Indonesia. The number of smartphone users that continues to grow from time to time seems to be in line with the increase in the number of online store accessors from the web and applications. Some websites that are frequently visited by students are online stores such as Shopie, Lazada, Toko Pedia, Bli Bli.com.

Marketing is one of the main activities that need to be carried out by companies, whether goods or services companies in an effort to maintain the viability of their business. This is because marketing is one of the company's activities, which are directly related to consumers. then marketing activities can be interpreted as human activities that take place in relation to the market, marketing also has an important activity in analyzing and evaluating all the needs and desires of consumers which also includes all activities within the company. One of them is about advertising how to do it creates new space in the product itself. According to Keegan and Green in Rahman, (2012:21) advertisements are messages that contain elements of art, text/writing, titles, photos, tagelines, other elements that have been developed for their suitability. A good advertisement must be able to convey the content of the message clearly. Focused on the segment, attractive and in accordance with advertising ethics. A good advertising strategy will contribute to the value of competition in the world of marketing which has led to a war between brands. This is because brands can influence consumer evaluations in the purchasing decision-making process. Therefore, it is very important for a brand to have a competitive advantage that can distinguish a brand from other brands. One way to build differentiation is to create a personality for the brand attractive and in accordance with advertising ethics. A good advertising strategy will contribute to the value of competition in the world of marketing which has led to a war between brands. This is because brands can influence consumer evaluations in the purchasing decision-making process. Therefore, it is very important for a brand to have a competitive advantage that can distinguish a brand from other brands. One way to build differentiation is to create a personality for the brand attractive and in accordance with advertising ethics. A good advertising strategy will contribute to the value of competition in the world of marketing which has led to a war between brands. This is because brands can influence consumer evaluations in the purchasing decision-making process. Therefore, it is very important for a brand to have a competitive advantage that can distinguish a brand from other brands. One way to build differentiation is to create a personality for the brand Therefore, it is very important for a brand to have a competitive advantage that can distinguish a brand from other 
brands. One way to build differentiation is to create a personality for the brand Therefore, it is very important for a brand to have a competitive advantage that can distinguish a brand from other brands. One way to build differentiation is to create a personality for the brand

Online advertising is an online marketing effort by displaying a website in search engine search results in a paid way. Online advertising can also be described as the activity of placing advertisements to offer products or services through cyberspace, the purpose of which is none other than to gain profits from sales activities. The advantage of online advertising is that it can target consumers based on consumer interests or according to the targets the company wants to achieve. In fact, online advertising payments are only paid for successful ones or in other words the company can pay according to the total clicks that enter the website. Because every consumer has the right to convenience, security, correct and honest information and the right treatment or service for what is purchased, then every company or producer is required to provide an excellent form of service to its consumers. This fact can be seen, that there are several things that can increase consumer buying interest, namely the total customer value consisting of product value, service value, personal value, image value, and total customer cost consisting of monetary costs, time costs, costs energy, and thought costs. At this time the use of e-commerce in the student environment is said to be quite rapid in its use and development and total customer costs consisting of monetary costs, time costs, labor costs, and thought costs. At this time the use of e-commerce in the student environment is said to be quite rapid in its use and development and total customer costs consisting of monetary costs, time costs, labor costs, and thought costs. At this time the use of e-commerce in the student environment is said to be quite rapid in its use and development

\section{PREVIOUS RESEARCH}

Previous research is an attempt by researchers to find comparisons and then to find new inspiration for further research. In addition, previous studies help researchers to position research and show the originality of the research. In this section, the researcher includes various previous research results related to the research to be carried out, then makes a summary, both published and unpublished research. The following is a previous study that is still related to the theme that the author is studying.

1. M.Taufik 2019 Faculty of Islamic Economics and Business Surakarta State Islamic Institute The Effect of Advertising Attractiveness to Online Purchase Intentions Through Intervening Variables Brand Image on Traveloka on Students of Febi Iain Surakarta Class of 2016-2017 This study aims to examine the effect of advertising attractiveness (X) on purchase intention $(\mathrm{Y})$, and whether the influence is mediated by brand image $(\mathrm{Z})$ or not. This research is quantitative research using descriptive method and Sobel Test. The sampling technique used purposive sampling method to 140 respondents using a questionnaire instrument. Respondents were students of the 2016-2017 Islamic Economics and Business Faculty of IAIN Surakarta who used the Traveloka application. The results of the statistical test of the $t$ test for the advertising attractiveness variable obtained tcount of $3,526>\mathrm{t}$ table of 1.977 with a p-value of $0.00064<$ of 0.05 , then the hypothesis is accepted. This means that the attractiveness of advertising has a significant effect on purchase intention. Thus the first hypothesis is proven, namely the attractiveness of advertising has a significant effect on purchase intention. 2. The Effect of Brand Image on Purchase Intention. The statistical test results of the t-test for the brand image variable obtained tcount of $5.311>$ ttable of 1.977 with a p-value of $0.000<$ of 0.05 , then the hypothesis is accepted. This means that brand image has a significant effect on purchase intention. Thus the first hypothesis is proven that brand image has a significant effect on purchase intention. This means that the attractiveness of advertising has a significant effect on purchase intention. Thus the first hypothesis is proven, namely the attractiveness of advertising has a significant effect on purchase intention. 2. The Effect of Brand Image on Purchase Intention. The statistical test results of the t-test for the brand image variable 
THE EFFECT OF ONLINE ADVERTISING (ONLINE ADVERTISING) ON CONSUMER BUYING INTEREST IN BUYING APPLICATIONS ONLINE WITH CUSTOMER SATISFACTION AS INTERVENING VARIABLE

(Case Study on Students of the Faculty of Economics and Business, Malikussaleh University)

obtained tcount of $5.311>$ ttable of 1.977 with a p-value of $0.000<$ of 0.05 , then the hypothesis is accepted. This means that brand image has a significant effect on purchase intention. Thus the first hypothesis is proven that brand image has a significant effect on purchase intention. This means that the attractiveness of advertising has a significant effect on purchase intention. Thus the first hypothesis is proven, namely the attractiveness of advertising has a significant effect on purchase intention. 2. The Effect of Brand Image on Purchase Intention. The statistical test results of the t-test for the brand image variable obtained tcount of $5.311>$ ttable of 1.977 with a p-value of $0.000<$ of 0.05 , then the hypothesis is accepted. This means that brand image has a significant effect on purchase intention. Thus the first hypothesis is proven that brand image has a significant effect on purchase intention. The Effect of Brand Image on Purchase Intention The results of the statistical test of the t-test for the brand image variable obtained tcount of $5.311>$ ttable of 1.977 with a p-value of $0.000<$ of 0.05 , then the hypothesis is accepted. This means that brand image has a significant effect on purchase intention. Thus the first hypothesis is proven that brand image has a significant effect on purchase intention. The Effect of Brand Image on Purchase Intention The results of the statistical test of the t-test for the brand image variable obtained tcount of $5.311>$ ttable of 1.977 with a p-value of $0.000<$ of 0.05 , then the hypothesis is accepted. This means that brand image has a significant effect on purchase intention. Thus the first hypothesis is proven that brand image has a significant effect on purchase intention.

2. Afifa Fahrika (2015) Effect of Online Advertising and E-Service Quality on Loyalty with Satisfaction as an Intervening Variable at Online Shop Joyism Malang Based on the solvin calculation in the determination of the sample. So, obtained the number of 93 respondents who were used as research samples. The results of the data that have been described in this study, it can be seen that the online marketing variables (X1), e-service quality (X2), and satisfaction (Y1) have a significant influence on the loyalty variable (Y2). Tests conducted online marketing (X1), e-service quality (X2) on loyalty (Y2) through satisfaction (Y1) got a one-tailed probability value of $0.00000685<0.05$ and $0.00032807<0.05$ which means that the satisfaction variable (Y1) can mediate between online marketing variables (X1), eservice quality (X2) on loyalty (Y2). It can be concluded that online marketing (X1) and eservice quality (X2) have an indirect effect on loyalty (Y2) through satisfaction (Y1). Online marketing uses advertising media to market a product or service which ultimately results in responses, responses and transactions where the online shop creates value for customers and builds what customers want. Likewise with e-service quality which is measured through services on the website provided by the online shop, when the customer feels the service on the website is good, the customer is loyal to the online shop and will make repeat purchases. Customer satisfaction is characterized by the absence of complaints, frequent shopping in large quantities,

3. Dini Agustina 2015 The Influence of Online Advertising Personalization on Consumer Attitudes and Purchase Interest Personal relevance (PR) has a positive influence on consumer attitudes as indicated by a value of $13.22(>1.96)$ with $\mathrm{p}<0.05$ so that $\mathrm{H} 1$ in this study is personal relevance in personalizing online advertising has a positive effect on consumer attitudes to be accepted. Personal relevance in online advertising personalization has a positive effect on consumer attitudes towards online advertising personalization. The irritation variable (IR) has no effect on consumer attitudes, which is indicated by a value of -1.57 (<1.96) so that $\mathrm{H} 2$, namely the level of irritation (Irritation) in personalizing online advertising, has a negative effect on rejected consumer attitudes. The results in this study indicate that the level of irritation caused by personalizing online advertising has no effect 
on consumer attitudes. The significance test was carried out for the privacy concern variable, which has a value of $-5.10(>1.96)$ so that $\mathrm{H} 3$ which is privacy concern in personalizing online advertising has a negative effect on consumer attitudes. The results in this study indicate that privacy concern has a negative influence on consumer attitudes. H4 in this study, namely consumer attitudes towards personalizing online advertising has a positive effect on consumer buying interest accepted, this is shown by the value of the relationship between consumer attitudes towards personalizing online advertising/attitude towards personalized online advertisement (ATT) with purchase intention (PI) which has a value of 18.99 (> 1.96). Consumer attitudes towards personalizing online advertising have a positive effect on consumer buying interest.

4. This means that the higher the attractiveness of online advertising, the higher the consumer's awareness of the AQUA brand bottled water and it will improve the AQUA brand image. Based on multiple linear regression analysis, it is known that brand image has a positive and significant influence on purchase intention. This means that the higher the AQUA brand image, the higher consumer buying interest in AQUA brand bottled water will be.

\section{IMPLEMENTATION METHOD}

3.1 Types and Sources of Data

3.1.1 Data Type

This research is a quantitative research, Quantitative data according to Sugiyono (2015) is data in the form of numbers or qualitative data that is numbered.

\subsubsection{Data Source}

Primary Data is a data source that directly provides data to data collectors. In this study, primary data in the form of data from questionnaires and interviews conducted by researchers.

Secondary data is a source that does not directly provide data to data collectors, for example through other people or through documents.

\subsection{Data Collection Techniques}

\subsubsection{Questionnaire}

Questionnaires or questionnaires are a number of questions or written statements about factual data or opinions relating to the respondent, which are considered facts or truths that are known and need to be answered by the respondent (Suroyo anwar 2009:168.). In this questionnaire, a closed question model will be used, namely questions that have been accompanied by previous alternative answers so that respondents can choose one of these alternative answers.

The data processing in this study used a Likert Scale.According to Sugiyono (2013:132), "Likert scale is used to measure attitudes, opinions and perceptions of a person or group of people about social phenomena".

In answering this Likert scale, the respondent only gives a mark, for example a checklist or a cross on the answer chosen according to the statement. The questionnaire that has been filled out by the respondent needs to be scored. The following is the weight of the assessment on the Likert scale.

\subsubsection{Interview}

According to Sugiyono (2015:231) interviews are data collection techniques if researchers want to conduct a preliminary study to find problems that must be investigated, but also if researchers want to know things from respondents more deeply. 
THE EFFECT OF ONLINE ADVERTISING (ONLINE ADVERTISING) ON CONSUMER BUYING INTEREST IN BUYING APPLICATIONS ONLINE WITH CUSTOMER SATISFACTION AS INTERVENING VARIABLE

(Case Study on Students of the Faculty of Economics and Business, Malikussaleh University) Asy'Ari Nisfullah, Armianto, Nazaina

Literature study, according to Nazir (2013), is a data collection technique by conducting a review study of books, literatures, notes, and reports that have to do with the problem being solved.

3.3 Population and Sample

3.3.1 Population

The population is a generalization area consisting of objects or subjects that have certain qualities and characteristics determined by researchers to be studied and drawn conclusions (Sugiyono, 2017). In this study, the population was students of the Faculty of Economics and Business, Malikussaleh University, as many as 40 people.

\subsubsection{Sample}

Sample According to (Sugiyono, 2016:81) that: "The sample is part of the number and characteristics possessed by the population. Measurement of the sample is a step to determine the size of the sample taken in carrying out research on an object. To determine the size of the sample can be done with statistics or based on research estimates. This sampling must be carried out in such a way that a sample is obtained that can truly function or can describe the actual state of the population, in other terms it must be representative.

Because the target population is less than 100, the sampling technique used is the census method, where the entire population is 40 students of Class A and B Regular semester VII. Faculty of Economics and Business, University of Malikussaleh which will be used as research samples.

3.4 Definition of Variable Operations

Definition of Variables According to Sugiyono (2013:58) the definition of a variable is:

"An attribute or nature or value of a person, object or activity that has a certain variation set by researchers to study and draw conclusions".

3.4.1 Independent Variables (Independent Variables)

The definition of independent variables according to Sugiyono (2013:39) is a variable that affects or is the cause of the change or the emergence of the dependent variable (dependent).

3.4.2 Bound Variable (Developed Variable)

The definition of the dependent variable according to Sugiyono (2013:39) is a variable that is influenced or becomes a result because of the independent variable.

3.4.3 Intervening Variable $(\mathrm{Z})$

Sugiyono (2013:61) states that: Intervening variables are variables that theoretically affect the relationship between the independent variable and the dependent variable, but cannot be observed and measured. This variable is an intervening variable or between which lies between the independent and dependent variables, so that the independent variable does not directly affect the change or emergence of the dependent variable ".

3.5 Data Analysis Techniques

Data analysis is a desire to group, make a sequence, manipulate and abbreviate data so that it is easy to read and understand. In other words, data analysis activities are raw data that has been collected and needs to be categorized or divided into several categories or groups, abbreviated in such a way that the data can answer the problem according to the research objectives and can test hypotheses (Silaen and Widiyono, 2013).

\section{RESEARCH RESULTS}

\subsection{Partial t-test}




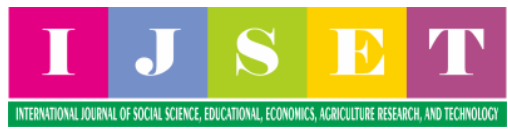

\begin{tabular}{|c|c|c|c|c|c|c|c|c|}
\hline \multicolumn{9}{|c|}{ Coefficientsa } \\
\hline \multirow{2}{*}{\multicolumn{2}{|c|}{ Model }} & \multicolumn{2}{|c|}{$\begin{array}{l}\text { Unstandardized } \\
\text { Coefficients }\end{array}$} & \multirow{2}{*}{$\begin{array}{c}\text { Standardized } \\
\text { Coefficients } \\
\text { Beta } \\
\end{array}$} & \multirow[b]{2}{*}{$\mathrm{t}$} & \multirow[b]{2}{*}{ Sig. } & \multicolumn{2}{|c|}{ Collinearity Statistics } \\
\hline & & $\mathrm{B}$ & Std. Error & & & & Tolerance & VIF \\
\hline \multirow[t]{2}{*}{1} & (Constant) & 2,041 & 2019 & & 1.011 & .318 & & \\
\hline & Ad_X & .906 & .122 & .769 & 7,413 & .000 & 1,000 & 1,000 \\
\hline
\end{tabular}

a. Dependent Variable: Satisfaction_Consumer_Z (Z).

Hypothesis Testing the effect of advertising variable $(\mathrm{X})$ on consumer satisfaction variable

The form of hypothesis testing based on statistics can be described as follows:

Decision Making Criteria:

1) Accept HO If tcount < ttable or -tcount $>$ - ttable orvalue Sig. $>0.05$

2) Reject HO If tcount ttable or -tcount - ttable orSig. $<0.05$

From table 4.16 , the tcount value is 7.413 . With $=5 \%$, ttable $(5 \%$; nk $=38)$ the ttable value is 2.024. From the description it can be seen that tcount (7.413) > ttable (2.024), as well as the significance value of $0.00<0.05$ then it can be concluded that the first hypothesis is accepted, meaning that the advertising variable $(\mathrm{X})$ has a positive and significant effect on consumer satisfaction (Z). This research is in accordance with Hammad Aqsa 2014 College of Economics Muhammadiyah Palopo Effect of Online Advertising on Attitudes and Interests in Buying Consumers Online in Palopo City (Survey of Internet Users in Palopo City) This research is an empirical study on internet users in Palopo city how attitudes and interests consumers buy online after seeing online ads

\begin{tabular}{|c|c|c|c|c|c|c|c|c|}
\hline \multicolumn{9}{|c|}{ Coefficientsa } \\
\hline & & \multicolumn{2}{|c|}{$\begin{array}{l}\text { Unstandardized } \\
\text { Coefficients }\end{array}$} & \multicolumn{2}{|l|}{$\begin{array}{l}\text { Standardized } \\
\text { Coefficients }\end{array}$} & & \multicolumn{2}{|c|}{$\begin{array}{c}\text { Collinearity } \\
\text { Statistics }\end{array}$} \\
\hline \multicolumn{2}{|c|}{ Model } & $\mathrm{B}$ & $\begin{array}{l}\text { Std. } \\
\text { Error }\end{array}$ & Beta & $\mathrm{t}$ & Sig. & Tolerance & VIF \\
\hline & (Constant) & .612 & 1,491 & & .410 & .684 & & \\
\hline & Ad_X & .426 & .139 & .377 & 3.059 & .004 & .409 & 2.446 \\
\hline & Satisfaction_Consumer_Z & .531 & .118 & .554 & 4.492 & .000 & .409 & 2.446 \\
\hline
\end{tabular}

a. Dependent Variable: INTEREST_Beli_Y

a. Hypothesis test the effect of advertising (X) to buying interest (Y)

The form of hypothesis testing based on statistics can be described as follows:

Decision Making Criteria:

a) Accept HO If tcount < ttable or -tcount $>$ - ttable orvalue Sig. $>0.05$

b) Reject HO If tcount ttable or -tcount - ttable orSig. $<0.05$

From table 4.17 , the tcount value is 3.059 . With $=5 \%$, ttable $(5 \%$; $n k=38)$ the ttable value is 2.024. From this description it can be seen that tcount (3.059) > ttable (2.024), and the significance value is $0.004<0.05$, it can be concluded that the second hypothesis is accepted, meaning that advertisement $(\mathrm{X})$ has a positive and significant effect on buying interest (Y). This research is in accordance with Hammad Aqsa 2014 College of Economics Muhammadiyah Palopo Effect of Online Advertising on Attitudes and Interests in Buying Consumers Online in Palopo City (Survey of Internet Users in Palopo 
THE EFFECT OF ONLINE ADVERTISING (ONLINE ADVERTISING) ON CONSUMER BUYING INTEREST IN BUYING APPLICATIONS ONLINE WITH CUSTOMER SATISFACTION AS INTERVENING VARIABLE

(Case Study on Students of the Faculty of Economics and Business, Malikussaleh University) Asy'Ari Nisfullah, Armianto, Nazaina

City) This research is an empirical study on internet users in Palopo city how attitudes and interests consumers buy online after seeing online advertisements.

b. Hypothesis Testing the influence of consumer satisfaction $(\mathrm{Z})$ on buying interest $(\mathrm{Y})$

The form of hypothesis testing based on statistics can be described as follows:

Decision Making Criteria:

a) Accept $\mathrm{HO}$ If tcount $<$ ttable or -tcount $>-$ ttable orvalue Sig. $>0.05$

b) Reject $\mathrm{HO}$ If tcount ttable or -tcount - ttable orSig. $<0.05$

From table 4.17, the tcount value is 4.492 . With $=5 \%$, ttable $(5 \%$; $\mathrm{nk}=38)$ the thable value is 2.024. From this description it can be seen that tcount (4.492) > ttable (2.024), and the significance value is $0,00<0.05$ then it can be concluded that the third hypothesis is accepted, it means consumer satisfaction $(\mathrm{Z})$ positive and significant effecton buying interest (Y). This research is not in accordance with the 2014 Hammad Aqsa College of Economics Muhammadiyah Palopo THE EFFECT OF ONLINE ADVERTISING ON CONSUMER ATTITUDES AND INTEREST TO BUY ONLINE IN PALOPO CITY (Survey on Internet Users in Palopo City) This research is an empirical study on internet users in the city of Palopo how attitudes and consumer buying interest online after seeing online advertisements.

4.2 Path Analysis

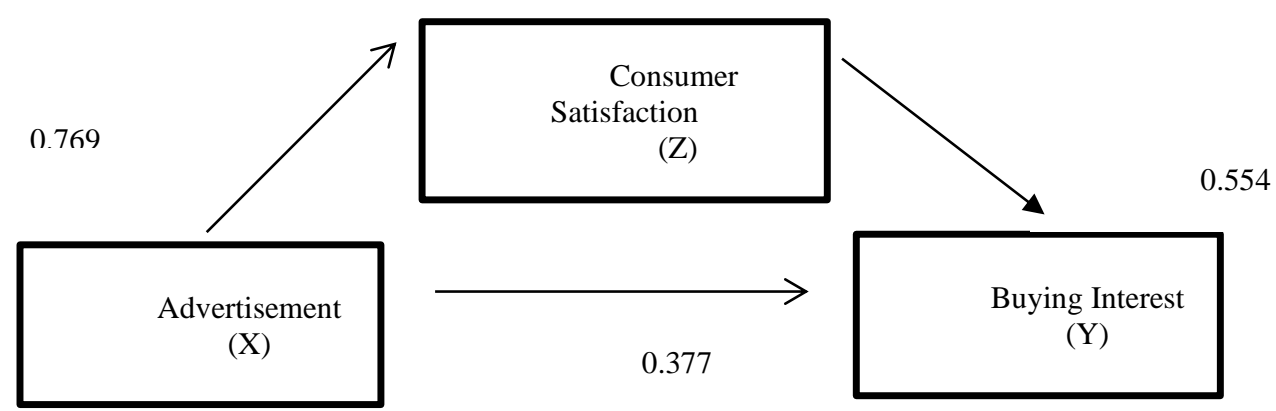

Path Analysis

Path analysis shows that the direct effect of variable $\mathrm{X}$ on variable $\mathrm{Y}$ is 0.377 . Meanwhile, the indirect effect through the $\mathrm{Z}$ variable is $0.769 \times 0.554=0.426$. From the calculation results obtained, the indirect effect through the $\mathrm{Z}$ variable is greater than the direct effect on the $\mathrm{Y}$ variable.

\section{CONCLUSION}

1) Based on the results of the study, the researcher concluded that descriptive advertising was in the high classification or in the good category. It can be seen from the advertising variable online $(\mathrm{X})$ take effect significant on consumer satisfaction $(\mathrm{Y})$. Theoretically, advertising can increase good consumer satisfaction, with the presence of advertisements having a major influence on buying interest.

2) Based on the results of the study, the researchers concluded that descriptive advertising is in a high classification or has a positive effect on buying interest. (X2)significant effect on buying interest (Y). Improving advertising can be done by paying attention to and meeting 
consumer needs properly so that it will be able to significantly influence advertising on buying interest.

3) Based on the results of the study, the researcher concluded that descriptive consumer satisfaction was in the high classification or had a positive effect on buying interest. Where is customer satisfaction (Z)significant effect on buying interest (Y). Consumer satisfaction can be done by paying attention to and meeting consumer needs properly so that it will be able to significantly influence buying interest.

4) Path analysis shows the direct effect of variable $X$ on variable $Y$ of 0.377 . Meanwhile, the indirect effect through the $\mathrm{Z}$ variable is $0.426 \times 0.554=0.426$. From the calculation results obtained, the indirect effect through the $\mathrm{Z}$ variable is greater than the direct effect on the $\mathrm{Y}$ variable.

\section{REFERENCES}

Assauri, Sofjan. 2013. Marketing Management. Jakarta : Rajawali Press

Arikunto, S. 2010. Research Procedures A Practical Approach.: Rineka Cipta. Jakarta

Buchory, Herry Achmad \& Djaslim Saladin. 2010. Marketing Management.: Linda Karya. Bandung

Bob Sabran. 2012. Marketing Management, vols 1 and 2, ed. 13, Jakarta, PT. Erlangga

Daryanto, \& Setyobudi, I. 2014. Excellent customer and service: Gava Media Yogyakarta

Daradjat, Zakiah. Etc. 2014 Al-Quran Educational Sciences, Jakarta: PT. Earth Literature

Fandy Tjiptono. 2012. Marketing Strategy, ed. 3, Yogyakarta

Buchari Alma. 2011. "Marketing Management and Marketing Services". Alphabeta Publisher: Bandung

Edy Sutrisno, 2009. Human Resource Management, Third Edition, Kencana Prenada Media Group, Jakarta

Ghozali, Imam. 2011. "Application of Multivariate Analysis With SPSS Program"

Diponegoro University Publishing Agency. Semarang

Hasibuan, Malay SP. 2017. Human Resource Management. Revised Edition. Jakarta: Earth Literacy.

Kotler, and Keller. 2012. "Marketing Management". Edition 12. Jakarta : Erlangga

Keller, Kevin L. 2013. "Strategic Brand Management; Building, Measuring, and Managing Brand Equity". Fourth Edition Harlow, English : Pearson Education Inc.

Kotler, Philip and Armstrong, Gary, (2014), "Principles of Marketing", 12th Edition, Volume 1 Translated by Bob Sabran. Erlangga.Jakarta

Mangkunegara, A. A, Anwar Prabu, 2011. Human Resource Management Company, Bandung: Youth Rosdakarya.

Nazir, Moh. 2013. "Research Methods". Indonesian Ghalia. Bogor

Sugiyono. 2012. "Business Research Methodology", Print 16. Alphabeta. Bandung

2013. "Quantitative, Qualitative and R\&D Research Methods". Alphabeta.CV. Bandung:

Siagian, Son. 2010. Human Resource Management. Jakarta: Earth Literacy

Rivai, Veithzal. 2011, Human Resource Management for Companies: from Theory to Practice, Jakarta 
Volume 1 Issue 1 (2021)

THE EFFECT OF ONLINE ADVERTISING (ONLINE ADVERTISING) ON CONSUMER BUYING INTEREST IN BUYING APPLICATIONS ONLINE WITH CUSTOMER SATISFACTION AS INTERVENING VARIABLE

(Case Study on Students of the Faculty of Economics and Business, Malikussaleh University) Asy'Ari Nisfullah, Armianto, Nazaina 